\title{
A Novel Role for Protein Tyrosine Phosphatase SHP1 in Controlling Glial Activation in the Normal and Injured Nervous System
}

\author{
Andrea Horvat, ${ }^{1}$ Franz-Werner Schwaiger, ${ }^{1}$ Gerhard Hager, ${ }^{1}$ Frank Bröcker, ${ }^{1}$ Robert Streif, ${ }^{1}$ \\ Pjotr G. Knyazev, ${ }^{2}$ Axel Ullrich, ${ }^{2}$ and Georg W. Kreutzberg ${ }^{1}$ \\ ${ }^{1}$ Department of Neuromorphology, Max-Planck-Institute of Neurobiology and 2Department of Molecular Biology, \\ Max-Planck-Institute of Biochemistry, D-82152 Martinsried, Germany
}

Tyrosine phosphorylation regulated by protein tyrosine kinases and phosphatases plays an important role in the activation of glial cells. Here we examined the expression of intracellular protein tyrosine phosphatase SHP1 in the normal and injured adult rat and mouse CNS. Our study showed that in the intact CNS, SHP1 was expressed in astrocytes as well as in pyramidal cells in hippocampus and cortex. Axotomy of peripheral nerves and direct cortical lesion led to a massive upregulation of SHP1 in activated microglia and astrocytes, whereas the neuronal expression of SHP1 was not affected. In vitro experiments revealed that in astrocytes, SHP1 associates with epidermal growth factor (EGF)-receptor, whereas in microglia, SHP1 associates with colony-stimulating factor (CSF)-1-receptor. In postnatal and adult moth-eaten viable ( $\left.\mathrm{me}^{\mathrm{v}} / \mathrm{mev}^{\mathrm{v}}\right)$ mice, which are characterized by reduced SHP1 activity, a strong increase in reactive astrocytes, defined by GFAP immunoreactivity, was observed throughout the intact CNS, whereas neither the mor- phology nor the number of microglial cells appeared modified. Absence of ${ }^{3}[\mathrm{H}]$-thymidine-labeled nuclei indicated that astrocytic proliferation does not occur. In response to injury, cell number as well as proliferation of microglia were reduced in $\mathrm{me} / \mathrm{me}^{\mathrm{v}}$ mice, whereas the posttraumatic astrocytic reaction did not differ from wild-type littermates. The majority of activated microglia in mutant mice showed rounded and ameboid morphology. However, the regeneration rate after facial nerve injury in $\mathrm{me}^{\mathrm{v}} / \mathrm{me}^{\mathrm{v}}$ mice was similar to that in wild-type littermates. These results emphasize that SHP1 as a part of different signaling pathways plays an important role in the global regulation of astrocytic and microglial activation in the normal and injured CNS.

Key words: tyrosine phosphorylation; signal transduction; protein tyrosine phosphatase SHP1; peripheral nerve axotomy; facial nerve; hypoglossal nerve; sciatic nerve; direct cortical lesion; microglial proliferation; mutant moth-eaten viable mice
Activation of astrocytes and the macrophage-related microglia, as a ubiquitous hallmark of different neuropathological states, is important in forming an environment that contributes to successful repair of damaged brain tissue (for review, see Norenberg, 1994; Rothwell and Hopkins, 1995; Masliah et al., 1996; Ebadi et al., 1997; Schwaiger et al., 1998; Tacconi, 1998). In various pathological states, the nervous tissue becomes a source and a target for different cytokines regulating the activation process of microglial and astrocytic cells (for review, see Eddelston and Mucke, 1993; Raivich et al., 1996; Ebadi et al., 1997). However, intracellular molecules that mediate the coupling between the cytokine receptors and modulation of gene expression in activated microglia and astrocytes in vivo are poorly characterized.

Binding of cytokines to specific receptors triggers tyrosine phosphorylation of different signaling molecules within the target cells (for review, see Karnitz and Abraham, 1995). Such modifications of protein tyrosine residues have also been implicated in the activation of microglial cells in response to brain injury (Karp et al., 1994). The state of tyrosine phosphorylation depends on

Received June 8, 2000; revised Nov. 2, 2000; accepted Nov. 14, 2000.

This work was supported by grants from the Deutsche Forschungsgemeinschaft (Schwerpunktprogramm "Molekulare Grundlagen neuraler Reparaturmechanismen" Schw684/2-1 and Na 289/2-3). We thank Anja Wöppel and Maria Koch for their excellent technical assistance, Dr. James Chalcroft and Robert Schorner for help with photographic and digital documentation, and Helma Tyrlas for her expert technical assistance with the cell culture work.

Correspondence should be addressed to Dr. Andrea Horvat, Department of Neuromorphology, Max-Planck-Institute of Neurobiology, Am Klopferspitz 18a, D-82152 Martinsried, Germany. E-mail: horvat@neuro.mpg.de.

Copyright (C) 2001 Society for Neuroscience $0270-6474 / 01 / 210865-10 \$ 15.00 / 0$ the balance between the antagonistic activities of protein tyrosine kinases and protein tyrosine phosphatases (PTPs). PTPs have been reported to be involved in both positive (signal enhancing) and negative (signal terminating) regulation of cytokine signaling (for review, see Hunter, 1995). For example the cytosolic SH2 domain-containing protein tyrosine phosphatase SHP1 (also known as SH-PTP1, PTP-1C, HCP, or PTPN6) appears to be a negative regulator of receptors for c-kit, colony stimulating factor-1 (CSF-1), interleukin (IL)-3, IL-4, and interferon (IFN)$\alpha / \beta$ in hematopoietic cells as well as of IFN- $\gamma$-receptor in cultured astrocytes (Yi and Ihle, 1993; Yi et al., 1993; Klingmuller et al., 1995; Chen et al., 1996; Massa and Wu, 1996, 1998; Paulson et al., 1996). In contrast, in epithelial cells SHP1 is positively involved in epidermal growth factor (EGF) and IFN- $\gamma$ signaling (Su et al., 1996; You and Zhao, 1997). A physiological role of SHP1 has been elucidated in the investigations of so-called motheaten $(\mathrm{me} / \mathrm{me})$ and moth-eaten viable $\left(\mathrm{me}^{\mathrm{v}} / \mathrm{me}^{\mathrm{v}}\right)$ mice, which display multiple hematopoietic abnormalities. Both mice strains carry a single base mutation in the SHP1 gene resulting in splicing defects. In the me/me mice no SHP1 protein is detectable, whereas the $\mathrm{me}^{\mathrm{v}} / \mathrm{me}^{\mathrm{v}}$ mutation leads to the production of two variant forms of SHP1 protein with reduced biological activity (for review, see Tsui and Tsui, 1994; Schultz et al., 1997).

Although the role of SHP1 in hematopoietic cells is well defined, little is known about SHP1 expression in the CNS and after brain injury. In the present study we examined the expression and regulation of SHP1 in the intact and injured adult rat and mouse brain and the signaling pathways, where SHP1 may be involved. Because 
of a longer viability of $\mathrm{me}^{\mathrm{v}} / \mathrm{me}^{\mathrm{v}}$ mice in comparison to $\mathrm{me} / \mathrm{me}$, these mice have been used to study the function of SHP1 in the injured nervous system in vivo using two models of CNS trauma: the facial motor nucleus after nerve lesion and the direct cortical lesion.

\section{MATERIALS AND METHODS}

Animals. Adult male Wistar rats (200-250 gm) were housed under standard laboratory conditions in the animal house of the Max-PlanckInstitute of Biochemistry (Martinsried, Germany). Wild-type C57BL/6J and SHP1 natural heterozygous mutants moth-eaten viable $(\mathrm{C} 57 \mathrm{BL} / 6 \mathrm{~J}-$ $H c p^{\text {mev }}$ ) mice were purchased from The Jackson Laboratory (Bar Harbor, ME). Homozygous and heterozygous mice were further bred in our animal house. All animal experiments and care protocols were approved by the Regierung von Oberbayern (AZ 211-2531-10/93 and AZ 211-2531-37/97).

Facial, hypoglossal, and sciatic nerve transection. Under ether anesthesia, the facial nerve was transected at the stylomastoid foramen; the hypoglossal nerve was cut where it passes the carotid artery, and the sciatic nerve was cut at the level of the sciatic notch. In all experiments the unoperated contralateral side served as a control. After the indicated time intervals $(3,7,14,28,42$, and $84 \mathrm{~d})$, animals were overdosed with chloral hydrate. The brains and lumbar spinal cords were quickly removed without perfusion and frozen at $-70^{\circ} \mathrm{C}$.

Direct cortical lesion (cortical stab wound). Adult rats and mice (normal littermates and $\mathrm{me}^{\mathrm{v}} / \mathrm{me}^{\mathrm{v}}$ ) were deeply anesthesized by intraperitoneal injection $(150 \mu \mathrm{l} / 100 \mathrm{gm}$ body weight of a mixture containing 6\% xylazine and $0.7 \%$ xylazinhydrochlorid) and placed in a stereotaxic apparatus. After the scalp was reflected, burr holes were positioned over the cerebral cortex at $6 \mathrm{~mm}$ caudal to bregma and $3.5 \mathrm{~mm}$ lateral to the sagittal suture. A 26 gauge needle, mounted in the stereotaxic apparatus, was angled $10^{\circ}$ away from the midline and inserted to a depth of $3.0 \mathrm{~mm}$ from the surface of the brain. After surgery, animals were allowed to survive for different time intervals $(1,3,7$, and $14 \mathrm{~d})$.

Cell culture. For astroglial primary cultures the cortices of newborn rats were homogenized, and the suspension was kept in a $75 \mathrm{~cm}^{3}$ uncoated Nunc culture flask in an incubator $\left(37^{\circ} \mathrm{C}, 5 \% \mathrm{CO}_{2}\right)$ and fed every $2 \mathrm{~d}$ with DMEM containing $15 \%$ fetal calf serum (FCS). After $14 \mathrm{~d}$ the cells were washed frequently in DMEM and shaken repeatedly and vigorously to eliminate neurons and oligodendrocytes. Microglial primary cultures were prepared using a slight modification of the method described by Giulian and Baker (1986). The whole brains of newborn Wistar rats were homogenized, and the cells were maintained in a $25 \mathrm{~cm}^{3}$ uncoated Nunc culture flask in the incubator and fed on days 7 and 12 with DMEM containing $15 \%$ FCS. After $14 \mathrm{~d}$ the microglial cells were harvested by rotary shaking of the primary culture for $2 \mathrm{hr}$ at $200 \mathrm{rpm}$. The cells in the supernatant were harvested, counted, and reseeded at a density of $5 \times$ $10^{6}$ cells per $10 \mathrm{~cm}$ tissue dishes in DMEM/15\% FCS for $3 \mathrm{~d}$. For growth factor stimulation, astrocytes were cultured in serum-free medium (SFM) consisting of DMEM supplemented with $100 \mathrm{IU} /$ penicillin and $0.1 \%$ FCS, whereas microglia were cultured in the same medium supplemented with $0.3 \%$ FCS. After $48 \mathrm{hr}$ in SFM, astrocytes were stimulated with recombinant mouse EGF $(100 \mathrm{ng} / \mathrm{ml})$ (Sigma, Taufkirchen, Germany) and microglia were stimulated with recombinant mouse CSF-1 (200 ng/ml) (R \& D Systems, Wiesbaden-Nordenstadt, Germany) for 0, 10,30 , and $60 \mathrm{~min}$ at $37^{\circ} \mathrm{C}$.

Isolation of RNA and synthesis of $c D N A$. For RNA isolation, rat brainstems were removed and deep-frozen. The facial nuclei were punched out from the unoperated and operated sides. Total RNA was isolated using the Trisolv method (Biotecx Laboratories, Houston, TX); reverse transcription was performed with the standard Promega (Madison, W I) protocol using oligo-dT primer (30 $\mathrm{min}$ at room temperature, 45 min at $42^{\circ} \mathrm{C}, 5$ min at $99^{\circ} \mathrm{C}$ ). cDNA was purified with the QIAquick PCR purification kit (Qiagen, Hilden, Germany).

Cloning of the rat SHP1-cDNA. To obtain an in situ probe, the rat SHP1-cDNA $(775$ bp) was amplified with the sense (5'CGCAAGAACCAGGGTGACTTCTC-3') and antisense primers (5'GCAGGATCACTCGGCTGTGGTC-3') based on the European Molecular Biology Laboratory accession number RNU77038/U77038. Amplifications were performed in a final volume of $12.5 \mu$ l containing 1 $\mu \mathrm{M}$ sense and $1 \mu \mathrm{M}$ antisense primer, $200 \mu \mathrm{M}$ dNTPs (MBI Fermentas, Vilnius, Lithuania), $1 \times$ PCR buffer $\left[16 \mathrm{~mm}\left(\mathrm{NH}_{4}\right)_{2} \mathrm{SO}_{4}, 67 \mathrm{~mm}\right.$ Tris- $\mathrm{HCl}$, $\mathrm{pH} 8.8,0.1 \%$ Tween-20], $3 \mathrm{~mm} \mathrm{MgCl}_{2}, 1 \mathrm{U}$ Taq polymerase (all from Eurobio, Les Ulice, France), and $1 \mu \mathrm{l}$ cDNA (operated rat facial nucle- us). The PCR was performed for 35 cycles under the following conditions: $10 \mathrm{sec}$ at $94^{\circ} \mathrm{C}, 20 \mathrm{sec}$ at $64^{\circ} \mathrm{C}, 40 \mathrm{sec}$ at $74^{\circ} \mathrm{C}, 5 \mathrm{~min}$ at $74^{\circ} \mathrm{C}$. The PCR product was blunted with Pfu polymerase (Stratagene, La Jolla, $\mathrm{CA}$ ), ligated into pZErO-1-vector (Invitrogen, Groningen, The Netherlands), and sequenced in the sequencing facility of the Max-PlanckInstitute of Neurobiology.

In situ hybridization. The cloned rat SHP1 fragment was PCR amplified using T7 or SP6 primers specific for pZErO-vector (Invitrogen). The PCR was performed for 25 cycles at $94^{\circ} \mathrm{C}$ denaturing for $10 \mathrm{sec}, 65^{\circ} \mathrm{C}$ annealing for $20 \mathrm{sec}$, and $74^{\circ} \mathrm{C}$ elongation for $30 \mathrm{sec}$. The template was purified using the QIAquick purification kit (Qiagen), and labeling was performed by transcription using either T7 or SP6 RNA-polymerase (Boehringer Mannheim, Mannheim, Germany) and $\alpha^{35}$ S-UTP (Amersham Life Sciences, Braunschweig, Germany). To allow diffusion of probe into the tissue, the labeled SHP1 RNA probe (775 bp) was hydrolyzed in carbonate buffer $\left(60 \mathrm{~mm} \mathrm{Na}_{2} \mathrm{CO}_{3}, 40 \mathrm{~mm} \mathrm{NaHCO}, \mathrm{pH}\right.$ 10.2 ) for $30 \mathrm{~min}$ at $60^{\circ} \mathrm{C}$ according to manufacturer's protocol (Boehringer Mannheim). The hydrolysis was stopped by adding the neutralization buffer (200 mm NaOAc, $1 \%$ (v/v) $\mathrm{CH}_{3} \mathrm{COOH}, \mathrm{pH}$ 6.0). The labeled RNA probe was precipitated and reconstituted in bidistilled water. The $20-\mu \mathrm{m}$-thick brain sections were fixed in $4 \%$ formaldehyde (FA) in $0.1 \mathrm{M}$ PBS for $20 \mathrm{~min}$, washed in PBS, treated with $10 \mathrm{mg} / \mathrm{ml}$ proteinase- $\mathrm{K}$ in $50 \mathrm{~mm}$ Tris- $\mathrm{HCl}$ and $5 \mathrm{~mm}$ EDTA for $10 \mathrm{~min}$, and then fixed again. After washing in distilled water, sections were acetylated with $0.25 \%$ acetic anhydride in $0.1 \mathrm{M}$ triethanolamine, rinsed with PBS, dehydrated in ascending ethanol series, defatted in chloroform, rinsed in ethanol, and air-dried. Thereafter sections were hybridized overnight at $55^{\circ} \mathrm{C}$ in a mixture (50\% formamide, $10 \mathrm{~mm}$ PBS, $20 \mathrm{~mm}$ Tris HCl, $5 \mathrm{~mm}$ EDTA, $10 \%$ dextransulfate, $1 \times$ Denhardt's reagents, $0.2 \%$ sodium lauryl sarcosine, $500 \mu \mathrm{g} / \mathrm{ml} \mathrm{t}$-RNA, $200 \mu \mathrm{g} / \mathrm{ml}$ ss-DNA) containing labeled probe $\left(2 \times 10^{6} \mathrm{cpm} / 100 \mu \mathrm{l}\right.$ hybridization mixture $)$. After hybridization, sections were washed in $10 \mathrm{~mm}$ dithiothreitol in $5 \times$ sodium chloride/sodium citrate at $55^{\circ} \mathrm{C}$ and treated with RNase. After washing, the sections were dehydrated in an ascending ethanol series, air-dried, and dipped in photographic emulsion (NTB-2, Kodak, Rochester, NY). After 14 d exposure at $4^{\circ} \mathrm{C}$, the sections were developed, counterstained with hematoxylin, dehydrated in a graded series of ethanol, and coverslipped with DePeX (Gurr, BDH, Poole, UK).

Semiquantitative RT-PCR. Semiquantitative analysis of SHP1 mRNA expression in facial nuclei at different time points $(0,3,7,14,28$, and $56 \mathrm{~d}$ ) after nerve axotomy was performed as described previously (Hager et al., 1999; Hol et al., 1999). For each time point, cDNA was analyzed from six rats in triplicate. PCRs were performed in a final volume of 12.5 $\mu \mathrm{l}$ containing $1 \mu \mathrm{M}$ sense and $1 \mu \mathrm{M}$ antisense primer, $1 \times$ PCR buffer, 1.5 $\mathrm{mM} \mathrm{MgCl}_{2}$ (Eurobio), $200 \mu \mathrm{M}$ dNTPs (MBI Fermentas), $1 \mu \mathrm{Ci}$ (=13 nM) $\left[\alpha^{-}{ }^{32} \mathrm{P}\right] \mathrm{dATP}, 1 \mu \mathrm{Ci}(=13 \mathrm{nM})\left[\alpha^{-32} \mathrm{P}\right] \mathrm{dCTP}$ (Amersham), and $1 \mu \mathrm{l}$ cDNA (unoperated or operated rat facial nuclei). The SHP1 fragment was amplified with the sense primer 5'-GCAGGCAGAGTCACTGCTGCAG-3' starting at position 539 and the antisense primer $5^{\prime}$ GCCTTGGGCTGGTCATTGAGCAC-3' starting at position 630. The housekeeping protein cyclophilin A was used as an internal reference, and the signal for SHP1 was normalized for the cyclophilin A signal, as described previously (Hager et al., 1999; Hol et al., 1999). PCR products of SHP1 and cyclophilin were cloned into pZErO-vector (Invitrogen), and their identity was confirmed with sequencing. For each experiment and cDNA synthesis, the number of PCR cycles for optimal PCR conditions was determined independently for each primer pair to obtain a logarithmic increase of PCR product. The optimal cycle conditions for SHP1 were as follows: $10 \mathrm{sec}$ at $94^{\circ} \mathrm{C}$ (with a $1 \mathrm{sec}$ time increment for each subsequent cycle), $20 \mathrm{sec}$ at $64^{\circ} \mathrm{C}, 40 \mathrm{sec}$ at $74^{\circ} \mathrm{C}$ for $32 \mathrm{cycles}$; for cyclophilin A, the conditions were $30 \mathrm{sec}$ at $94^{\circ} \mathrm{C}$ (with a $1 \mathrm{sec}$ time increment for each subsequent cycle), $10 \mathrm{sec}$ at $59^{\circ} \mathrm{C}$, and $40 \mathrm{sec}$ at $74^{\circ} \mathrm{C}$ for 25 cycles. Semiquantitative and statistical analyses (a paired, two-tailed Student's $t$ test) for SHP1 mRNA expression were further performed as described previously (Hager et al., 1999; Hol et al., 1999).

Western blotting and immunoprecipitation. Rat or mouse facial motor nuclei homogenates were prepared in $100 \mu 1$ lysis buffer (50 mM HEPES, pH 7.5, $150 \mathrm{~mm} \mathrm{NaCl}, 1.5 \mathrm{~mm} \mathrm{MgCl}_{2}, 5 \mathrm{~mm}$ EGTA, $10 \%$ glycerin, $1 \%$ Triton X-100, $0.1 \mathrm{mM} \mathrm{Na}_{3} \mathrm{VO}_{4}, 10 \mu \mathrm{g} / \mathrm{ml}$ aprotinine, $10 \mu \mathrm{g} / \mathrm{ml}$ leupeptine, $1 \mathrm{~mm}$ phenylmethylsulfonyl) by homogenization. Lysates were then centrifuged at $12,000 \times g$ for $20 \mathrm{~min}$ at $4^{\circ} \mathrm{C}$, and the supernatants were transferred to new tubes. The protein concentration was quantified using a modification of the Bradford assay (Bio-Rad, Munich, Germany). Cell lysate protein $(20 \mu \mathrm{g})$ was electrophoresed through $7.5 \%$ SDS polyacrylamide gels and electroblotted on nitrocellulose membrane (Schleicher \& 

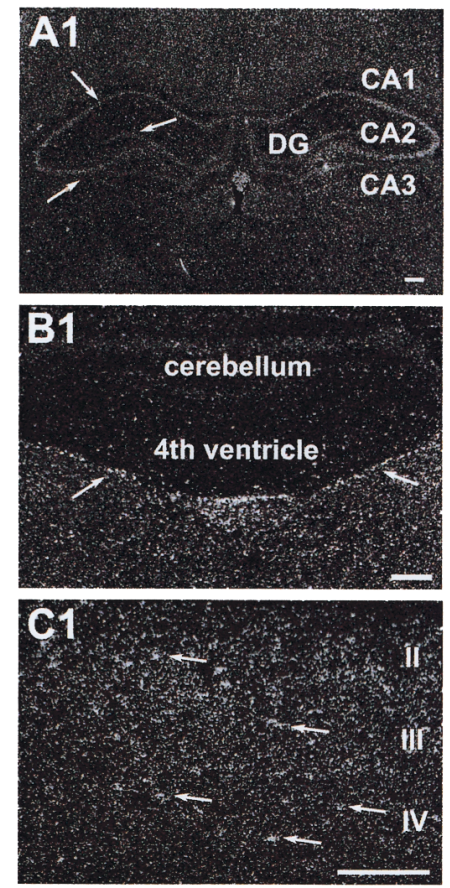

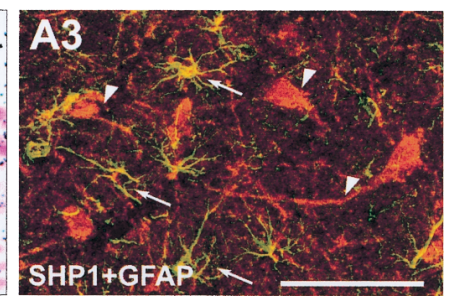

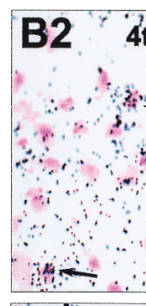
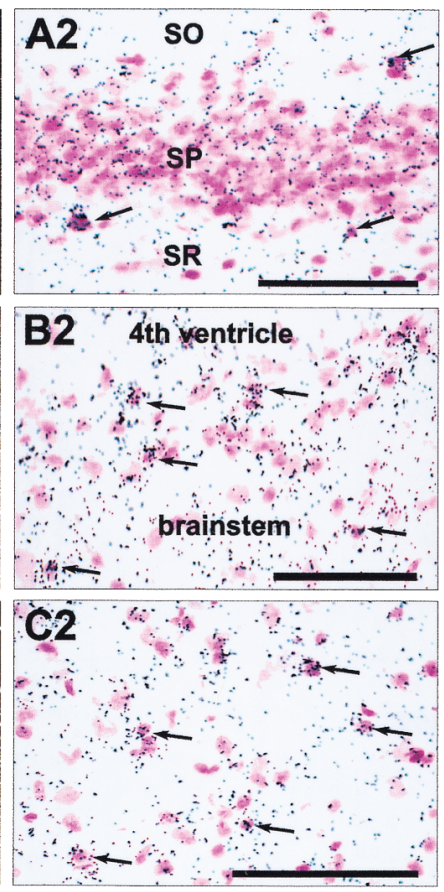

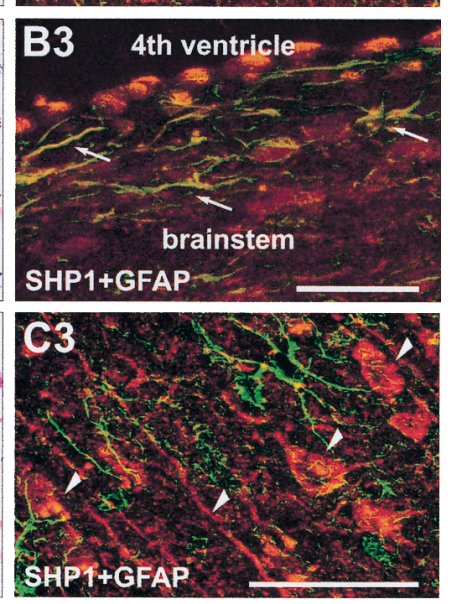

Figure 1. Expression of SHP1 mRNA and protein in the normal adult rat brain. The dark-field, hematoxylinstained, light-field micrographs and double-labeling immunohistochemistry for SHP1 and GFAP show coronal brain sections through the hippocampus $(A 1, A 2, A 3)$, through the brainstem $(B 1, B 2, B 3)$, and through the cortical layers II-IV $(C 1, C 2, C 3)$. Note that in the stratum oriens of hippocampus (A3) and in the brainstem in ependymal and subependymal layers lining the fourth ventricle (B3), SHP1 immunoreactivity colocalizes (yellow; arrows) on GFAPpositive astrocytes. In hippocampus (A3) and in cortical layers II-IV (C3), SHP1 immunoreactivity (red; arrowheads) is also located on pyramidal neurons and their apical dendrites. SO, Stratum oriens; $S P$, stratum pyramidale; $S R$, stratum radiatum. Scale bars, $100 \mu \mathrm{m}$.
Schuell, Dassel, Germany). The blots were incubated overnight at $4^{\circ} \mathrm{C}$ with rabbit anti-SHP1 (1:2000, Santa Cruz Biotechnology) or the mouse anti-actin antibodies (1:1000, Amersham) in $10 \mathrm{~mm}$ Tris, $\mathrm{pH} 8.0,150 \mathrm{~mm}$ $\mathrm{NaCl}$, and $0.05 \%$ Tween 20 containing $1 \%$ BSA.

For immunoprecipitation, the microglial or astrocytic cultured cells $\left(\sim 5 \times 10^{6}\right.$ cells $)$ were lysed in lysis buffer as described above. After centrifugation $\left(12,000 \times g, 20 \mathrm{~min}, 4^{\circ} \mathrm{C}\right)$ of cell lysates, rabbit anti-SHP1 antibodies (Santa Cruz Biotechnology) and protein A-Sepharose 4B (Pharmacia Biotech, Freiburg, Germany) were added. The mixtures were rotated at $4^{\circ} \mathrm{C}$ overnight, and the precipitates were washed in cold lysis buffer four times before SDS-electrophoresis analysis and Western blotting. For Western blotting, protein samples, separated on SDS-PAGE gels, were blotted to nitrocellulose membrane (Schleicher \& Schuell). The membranes were then incubated with mouse anti-phosphotyrosine antibody 4G10 (1:5000, Upstate Biotechnology, Lake Placid, NY), mouse anti-SHP1 antibodies (1:1000, Transduction Laboratories, San Diego, CA), rabbit anti-EGF-R antibodies (1:1000, Santa Cruz Biotechnology), or rabbit anti-CSF-1-R antibodies (a gift from Dr. Axel Ullrich, Department of Molecular Biology, Max-Planck Institute for Biochemistry, Martinsried, Germany).

In all Western blotting experiments, detection of primary antibodies was performed by incubating the membrane for $1 \mathrm{hr}$ at room temperature with secondary goat anti-rabbit or anti-mouse IgG coupled to horseradish peroxidase (Pierce, Rockford, IL). Specific antibody signals were detected using the enhanced chemiluminiscence kit (ECL, Amersham).

Immunohistochemistry. For all immunohistochemical studies, cryostat sections from fresh material were air-dried and fixed with $4 \%$ formaldehyde in $0.01 \mathrm{PBS}$ for $10 \mathrm{~min}, 50 \%$ acetone for $2 \mathrm{~min}, 100 \%$ acetone for

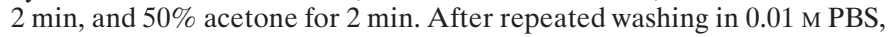
the sections were incubated overnight at $4{ }^{\circ} \mathrm{C}$ with primary antibodies. Thereafter the slices were rinsed in $0.01 \mathrm{M}$ PBS and incubated with secondary antibodies for $2 \mathrm{hr}$ at room temperature.

Immunofluorescence/confocal laser microscopy. Titration of the polyclonal rabbit anti-human SHP1 antibody (Santa Cruz Biotechnology) on cryostat tissue sections, $3 \mathrm{~d}$ after facial nerve axotomy, from 1:50 to 1:40,000 dilution revealed optimal staining intensity at 1:5000 dilution, which was used throughout the following study. Thereafter the slices where incubated with goat anti-rabbit IgGs coupled to indocarbocyanin (Cy3, 1:400; Dianova, Hamburg, Germany). Astrocytes were identified using antibodies directed against GFAP (Zymed, San Francisco, CA). Microglia in rat brain slices were identified using antibodies against Ox42 (Serotec, Oxford, UK). For colocalization studies (triple staining), the rabbit anti-SHP1/goat anti-rabbit Cy3 brain sections were first incubated with mouse anti-Ox42 antibodies (1:2000), which were visualized by goat anti-mouse IgGs coupled to indodicarbocyanin (Cy5, 1:400; Dianova) and additionally with rat anti-GFAP antibodies (1:100) detected by donkey anti-rat IgGs coupled to dichlorotriazinylamino-fluorescein (DTAF, 1:200; Dianova). In the direct cortical lesions section for colocalization of SHP1 we used the following: (1) with T-lymphocytes, hamster antibody against CD3-antigen (1:1000, PharMingen, San Diego, CA) detected by goat anti-hamster DTAF (1:200, Dianova); (2) with macrophages/monocytes, mouse antibody against ED1-antigen (1:100, Serotec) detected by goat anti-mouse DTAF (1:200, Dianova). Galanin was detected by rabbit antibody against galanin (1:5000, Penisula, Heidelberg, Germany). The sections were evaluated using a confocal laser scanning microscope in an inverted configuration (Leica TCS 4D, Leica, Bensheim, Germany). Consecutive optical sections up to $20 \mu \mathrm{m}$ depth in the slices were taken in two-channel mode, and each channel was projected into a two-dimensional micrograph using the maximum intensity projection algorithm. To avoid cross-talk between the red, green, and infrared channels, all fluorescence images were recorded in sequential mode.

Light microscopic immunohistochemistry. Mouse brain sections $(20 \mu \mathrm{m})$ from normal littermates and mutant $\mathrm{me}^{\mathrm{v}} / \mathrm{me}^{\mathrm{v}}$ mice were incubated with either rat monoclonal antibodies against $\alpha_{\mathrm{M}} \beta_{2}$-integrin (1:6000, Serotec) or rat monoclonal antibodies against GFAP (Zymed). Longitudinal sections $(10 \mu \mathrm{m})$ of the facial nerve were incubated with either rabbit polyclonal antibodies against galanin (1:400, Penninsula) or calcitonin gene-related peptide (CGRP) (1:1000, Penninsula). Primary antibodies were detected using appropriate biotinylated goat antibodies (1:100, Camon, Wiesbaden, Germany) and ABC peroxidase complex (Vector, Burlingame, CA) followed by diaminobenzidine kit (Pierce).

Quantification of cell proliferation and microglial cell number using bright-field microscopy. To quantify cell proliferation ( 2 and $3 \mathrm{~d}$ after facial nerve axotomy), both $\mathrm{me}^{\mathrm{v}} / \mathrm{me}^{\mathrm{v}}$ mice and wild-type littermates were injected intraperitoneally with a single dose of $\left[{ }^{3} \mathrm{H}\right]$-thymidine (Amersham) $(10 \mu \mathrm{Ci} / \mathrm{gm}$ body weight $) 2 \mathrm{hr}$ before they were killed (Raivich et al., 1994). After direct cortical lesion, each animal received (2 $\mathrm{d}$ after lesion) four consecutive intraperitoneal injections of $\left[{ }^{3} \mathrm{H}\right]$ thymidine $(10 \mu \mathrm{Ci} / \mathrm{gm}$ body weight per injection) separated by $3 \mathrm{hr}$ intervals (Janeczko, 1993). Autoradiography with NTB2 photoemulsion (Kodak) was performed after overnight $4 \%$ formaldehyde (in $10 \mathrm{~mm}$ PBS) fixation of fresh cryostat sections as described previously (Raivich et al., 1994). To determine the type of proliferating glial cells, immunohistochemistry ( $\alpha_{\mathrm{M}} \beta_{2}$-integrin labeling of microglia and GFAP labeling of astrocytes) (see Immunohistochemistry) was performed on fresh tissue sections from animals treated with $\left[{ }^{3} \mathrm{H}\right]$-thymidine, followed by autoradiography. The number of $\left[{ }^{3} \mathrm{H}\right]$-thymidine-positive cells and $\alpha_{\mathrm{M}} \beta_{2}$-immunopositive microglia were scored under a $40 \times$ objective in bright field. The total number of cells in 20 random fields per section was 
recorded. In all experiments the counts from six sections from each animal were added, and the means of four animals per time point were graphed. For statistical analyses, a paired, two-tailed Student's $t$ test was used.

Regeneration rate in the facial nerve. The facial nerve regeneration rate in $\mathrm{me}^{\mathrm{v}} / \mathrm{me}^{\mathrm{v}}$ mice and wild-type littermates was performed as described previously (Werner et al., 2000). Briefly, the facial nerve was crushed near the stylomastoid foramen for $30 \mathrm{sec}$. Four days after facial nerve crush, the animals were killed, followed by a 5 min perfusion with $4 \%$ FA-PBS and then by slow 60 min perfusion with $1 \%$ FA-PBS. The facial nerves were then dissected, frozen on dry ice, and cut longitudinally (10 $\mu \mathrm{m})$, and the regenerating axons were visualized by immunostaining for galanin or CGRP. Every fifth section was used per antibody, and the distance between the crush side and the most distal-labeled growth cone was measured using light microscopic grid scaling. The average distance for each animal $(n=6)$ was calculated from five tissue sections, and a paired, two-tailed Student's $t$ test was used for statistical analyses.

Confocal microscopy/quantitative fluorescence immunohistochemistry. To quantify the GFAP immunoreactivity (IR) in astrocytes, digital micrographs of the DTAF fluorescence $(1024 \times 1024$ pixels, $0-255 / 8$ bit gray scale) were recorded subsequently with a Leica TCS 4D confocal laser scanning microscope, $10 \times$ objective, and constant $\mathrm{ArKr}$ laser power. Fifteen consecutive equidistant levels were scanned per slice (total vertical span $=20 \mu \mathrm{m}$ ). From this stack, two-dimensional projections (1-Mbyte TIFF.files) were made using the maximum intensity projection algorithm provided by the microscope software. Quantification of GFAP immunoreactivity was performed with a slight modification of a method described previously (Sanner et al., 1993). The micrographs were analyzed using an image analysis program (OPTIMAS 6.2, Optimas Corporation, Bothell, WA). Regions of interest were built by the selection of the astrocytic cells, applying a threshold that was set to mean $+\mathrm{SD}$ of the mean (mean = average pixel intensity of the picture). This threshold, defined on the axotomized side, was also used for the respective control side. To test significance, a paired, two-tailed Student's $t$ test was performed between control sides of normal and moth-eaten viable littermates or between axotomized sides of normal and moth-eaten viable littermates. The counts from six sections from each animal were averaged, and the means of four animals per time point were graphed.

\section{RESULTS}

\section{SHP1 is constitutively expressed in astrocytes and pyramidal neurons in the normal CNS}

To determine whether SHP1 is expressed in the normal rat CNS, tissue sections of brain and cervical spinal cord were processed for in situ hybridization and immunohistochemistry. Strong SHP1 hybridization signal was found in CA1, CA2, and CA3 regions of hippocampus and in dentate gyrus (Fig. 1A1, A2), in ependymal and subependymal layers along the third ventricle (Fig. 1A1), the fourth ventricle (Fig. 1B1, B2), and the central canal of the spinal cord (data not shown) as well as in cortical layers (II-IV) (Fig. $1 C 1, C 2)$. In addition, a weak hybridization signal, slightly above the background, was evidently dispersed throughout the whole gray matter of brain parenchyma. Controls performed with sense cRNA transcripts did not show any specific cellular signal (data not shown). Immunohistochemistry showed that SHP1 immunoreactivity colocalized with GFAP-positive astrocytes (Fig. 1A3, $B 3)$. It appeared that most, if not all, astrocytes were labeled, whereas Bergmann glia in cerebellum remained negative. No SHP1 labeling on microglial cells was observed. In hippocampus and in cortical layers (II-IV), SHP1 immunoreactivity was also localized on the pyramidal neurons and their apical dendrites (Fig. 1A3, C3).

\section{Regulation of SHP1 is associated with glial cell activation in response to injury in the nervous system}

SHP1 mRNA and protein expression in response to brain injury was studied in peripheral (facial, hypoglossal, and sciatic) nerve axotomy models and after direct cortical lesion. Hybridization with the SHP1-specific cRNA probe on brain slices $3 \mathrm{~d}$ after
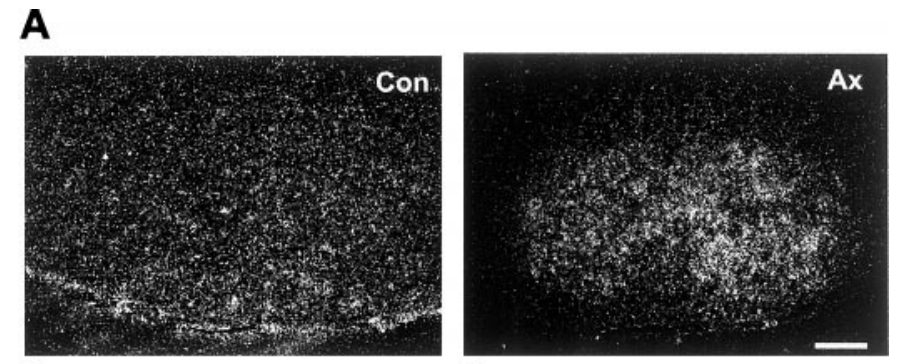

\section{B}

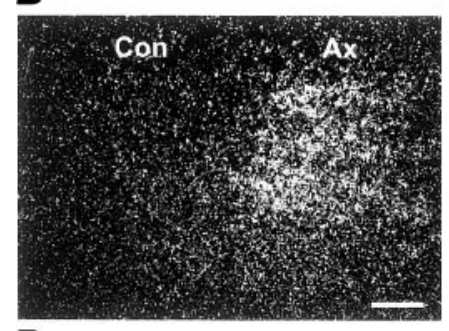

C
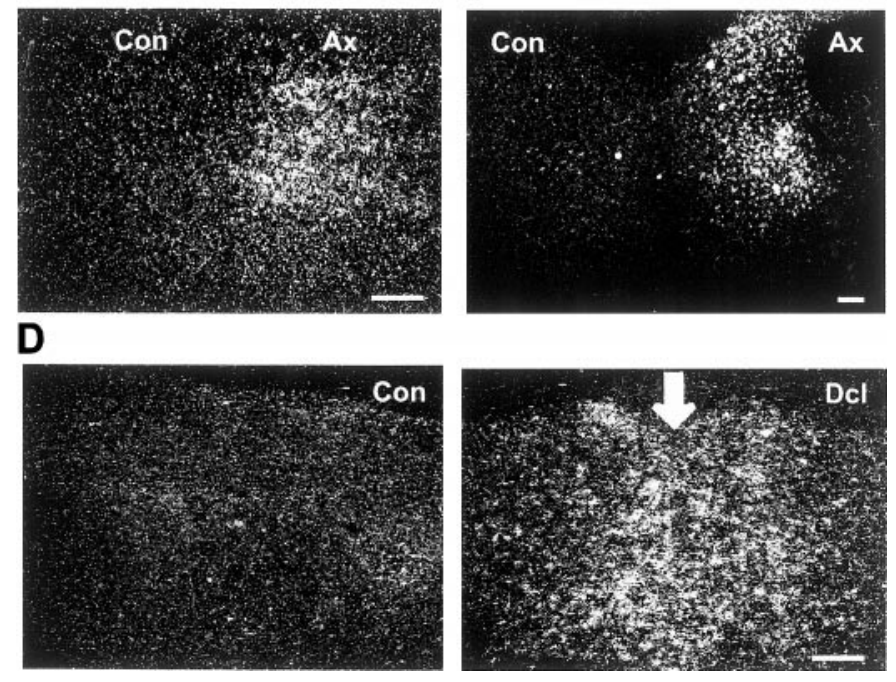

\section{D}

Figure 2. Regulation of SHP1 mRNA expression after peripheral (facial, hypoglossal, sciatic) nerve axotomy and direct cortical lesion $3 \mathrm{~d}$ after injury. The dark-field micrographs illustrate massive induction of the SHP1 mRNA expression in the axotomized $(A x)$ facial $(A)$ and hypoglossal $(B)$ motor nuclei. The SHP1 mRNA is also upregulated in ventral and dorsal gray matter of the lumbar spinal cord after sciatic nerve axotomy $(C)$. In response to direct cortical lesion $(D c l)$, upregulation of SHP1 mRNA is observed only within and around the brain wound $(D)$. In all injury models, weak hybridization signals, slightly above the background, are present on the control, unoperated side (Con). Scale bars, 200 $\mu \mathrm{m}$.

operation revealed an increase of silver grains over the axotomized facial (Fig. 2A) and hypoglossal motor nuclei (Fig. $2 B$ ) as well as over ventral and dorsal gray matter of the lumbar spinal cord (Fig. $2 C$ ). In the facial nerve axotomy model, the hybridization signal on the axotomized side reached a maximum of intensity at day 3 after operation and disappeared almost completely at $28 \mathrm{~d}$ after injury (Fig. 3B). After direct cortical lesion, SHP1 mRNA was also upregulated in the injured area, whereas signal intensity decreased rapidly with increasing distance from the lesion site (Fig. 2D). The hybridization signal persisted over the whole observation period (1-14 d after direct cortical lesion). In all injury models, very faint signals, almost near background, were detectable on the contralateral, unoperated sides. Controls performed with sense cRNA transcripts did not show any specific cellular signal (data not shown).

To exclude possible cross-hybridization effects of the SHP1 probe with other phosphatases and to quantify the increase of SHP1 mRNA after injury, semiquantitative PCR analysis was performed on cDNA obtained from axotomized and nonaxotomized (control) facial nuclei (Fig. $3 A$ ). The maximum in SHP1 mRNA upregulation was reached at $3 \mathrm{~d}$ after operation compared with control (10.4 \pm 4.6-fold increase; $n=6$; paired, two-tailed Student's $t$ test, $p<0.001)$. This increase in the expression of 


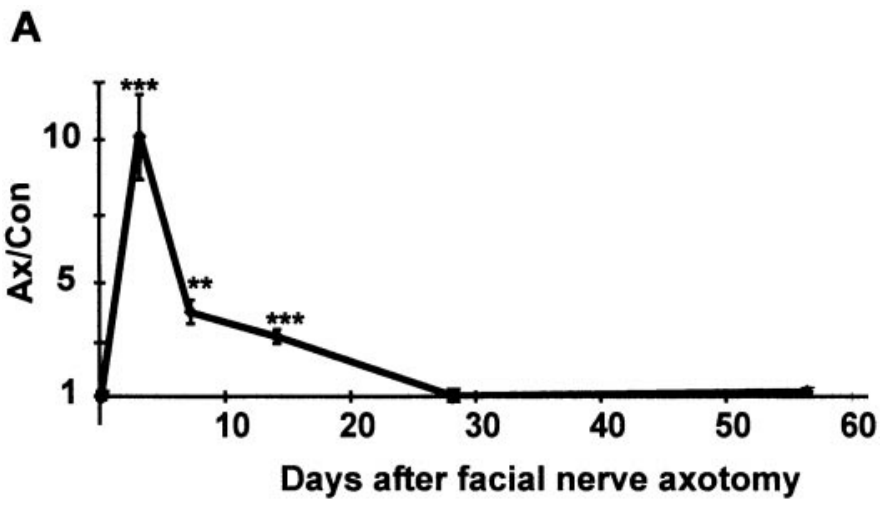

B
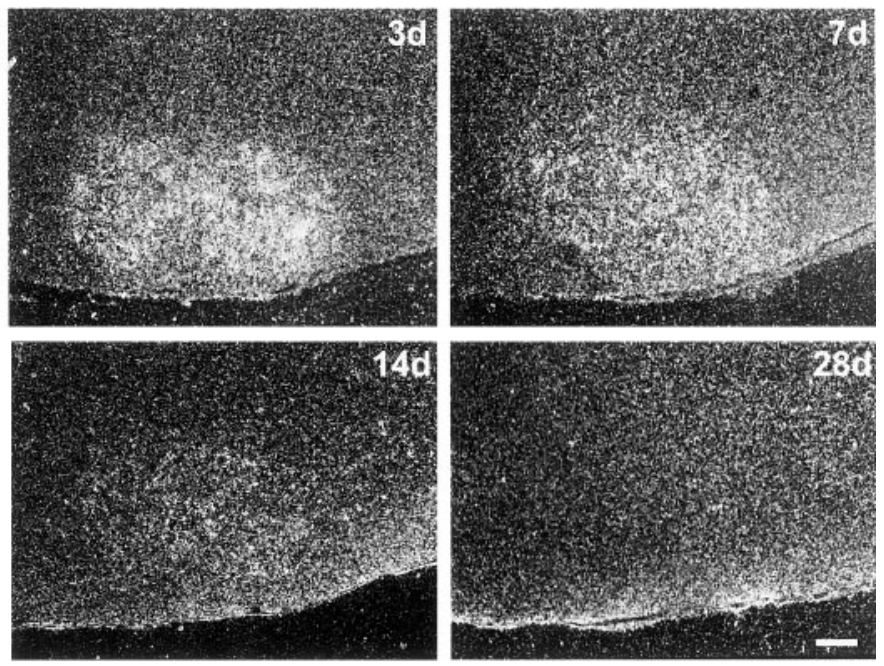

C

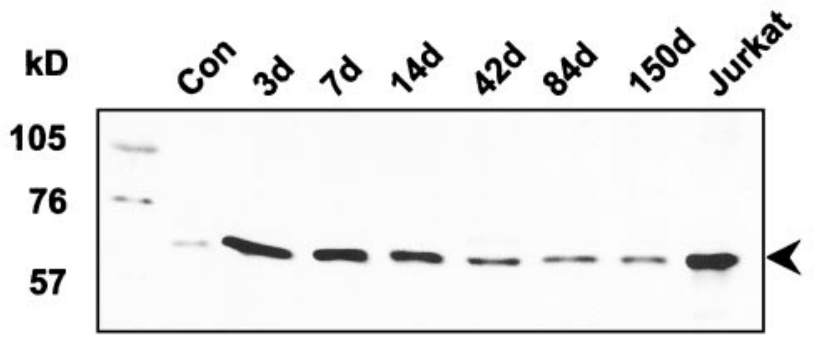

beta-actin

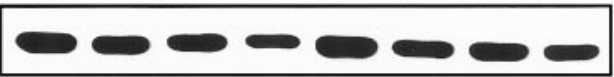

Figure 3. Time course of SHP1 mRNA and protein expression in the axotomized facial motor nucleus (3-150 d after transection). A, Quantification of SHP1 mRNA using semiquantitative RT-PCR. For each time point the relative increase compared with control facial nucleus was calculated $\left({ }^{* *} p<0.01\right.$ and ${ }^{* * *} p<0.001$; paired, two-tailed Student's $t$ test; $n=6$ per each time point). $B$, Dark-field micrographs of in situ hybridization sections $3,7,14$, and $28 \mathrm{~d}$ after facial nerve axotomy. Note the similarity between the in situ hybridization and PCR quantification in the time course of SHP1 regulation. $C$, Western blot analysis of SHP1 protein in the axotomized facial nucleus. Jurkat cells served as a positive control overexpressing SHP1 protein (68 kDa, arrow). Position of the molecular size marker (in kilodaltons) is indicated on the left. The protein levels of $\beta$-actin in cell lysates were also detected as a control for loading variations. Scale bar, $200 \mu \mathrm{m}$.
A
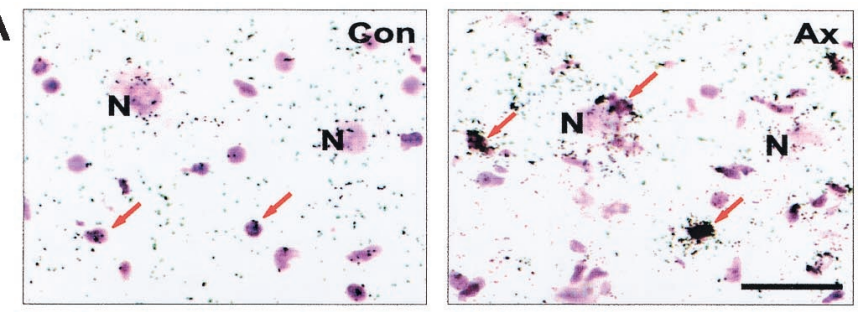

B
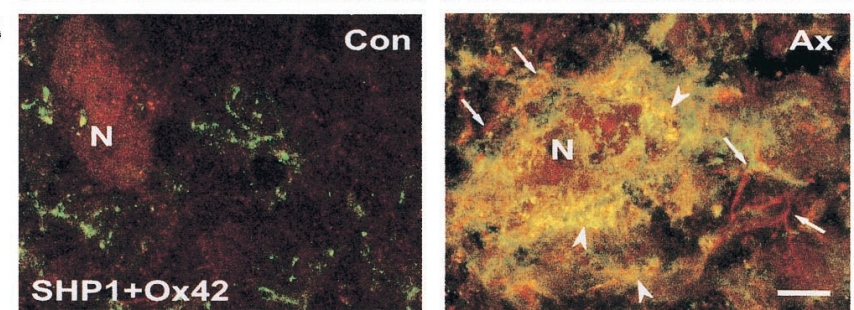

C
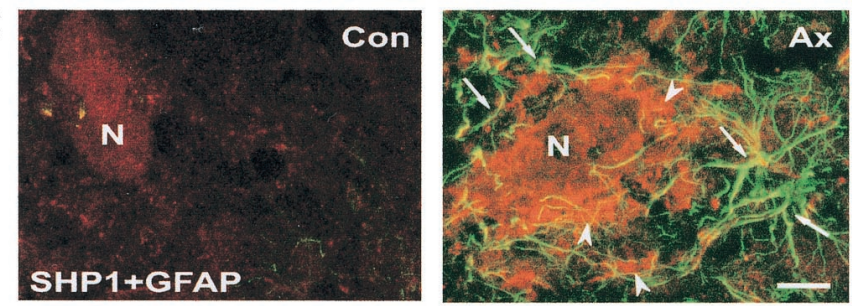

D
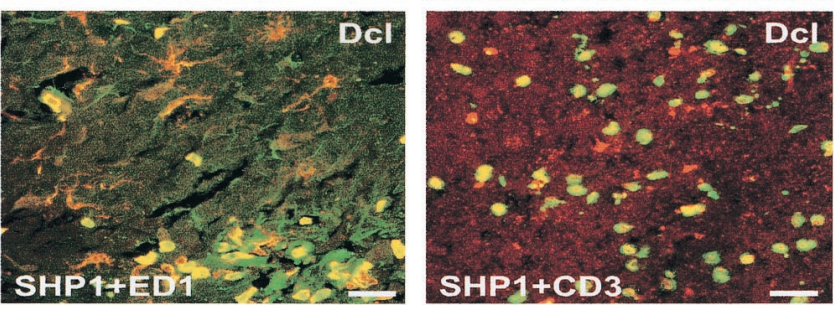

Figure 4. Cellular localization of SHP1 mRNA and protein $3 \mathrm{~d}$ after transection of the facial nerve and $1 \mathrm{~d}$ after direct cortical lesion. $A$, Light micrographs of hematoxylin-stained in situ hybridization sections show that silver grains accumulate over small, darkly staining nuclei (red arrows) in the axotomized facial nucleus, whereas motoneurons remain unlabeled. $B, C$, Facial motor nuclei $3 \mathrm{~d}$ after facial nerve transection, triple labeling for Cy3 (anti-SHP1, red), Cy5 (B, microglia, anti-Ox42; green), and DTAF ( $C$, astrocytes, anti-GFAP; green). After transection of the facial nerve, SHP1-IR (red) colocalizes (red and green overlap resulting in yellow) with Ox42-IR on activated microglia ( $B$, arrowheads) and GFAP-IR on astrocytes ( $C$, arrows). $D$, After direct cortical lesion, invading macrophages identified by anti-ED-1-antibody (green) and a subpopulation of T-lymphocytes identified by anti-CD3-antibody ( green) are also positive for SHP1-IR (red, colocalization in yellow). $N$, Neuron; Con, control, unoperated side; $A x$, axotomized side; $D c l$, direct cortical lesion side. Scale bars, $100 \mu \mathrm{m}$.

SHP1 mRNA declined after $14 \mathrm{~d}$, and no significant difference between the facial nucleus of the axotomized side and the control side could be measured 28 and $56 \mathrm{~d}$ after axotomy. The time course of SHP1 mRNA regulation in the PCR analysis paralleled the data obtained by in situ hybridization experiments (Fig. 3B).

To determine the cell types that upregulate SHP1 mRNA after peripheral and CNS lesions, the in situ hybridization slides were counterstained with hematoxylin (Fig. $4 A$ ). Silver grains strongly accumulated over non-neuronal, small cells on the injured side, whereas neurons remained unlabeled. On the control side, a faint accumulation of silver grains was also found over some nonneuronal cells. Triple-labeling immunohistochemistry revealed a strong increase in the IR for SHP1 (shown in red) on the injured side, which was found on Ox42-positive microglia (Fig. 4B, 
A
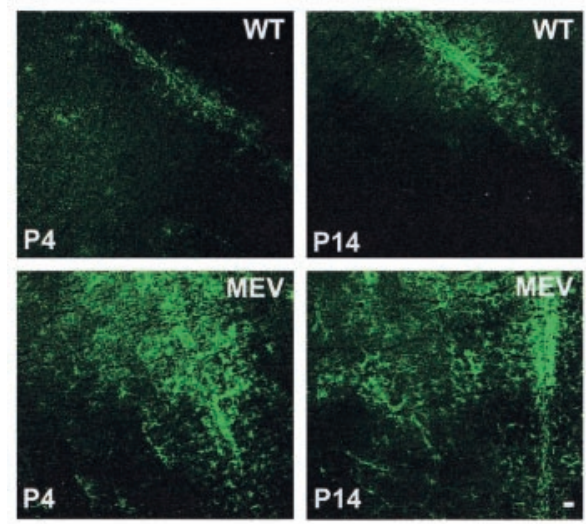

B
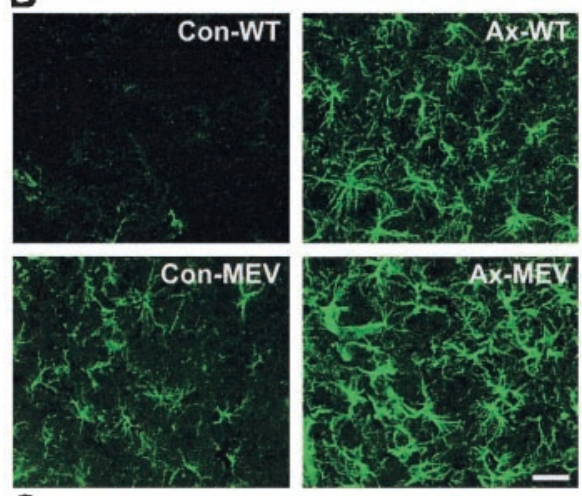

C
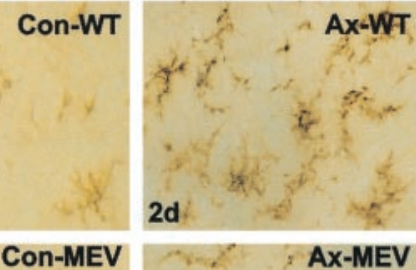

2d
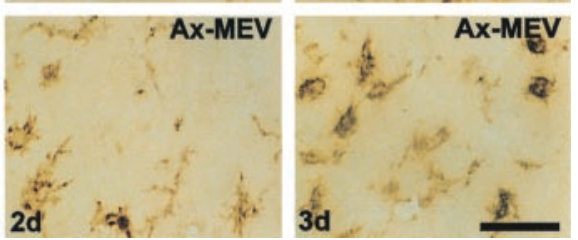

Figure 5. Astrocytic and microglial reaction in the intact brain during adulthood, in the intact (Con) and axotomized $(A x)$ facial nucleus in normal, wild-type littermates $(W T)$ and SHP1 mutant, moth-eaten viable mice $(M E V)$. $A$, GFAP-immunoreactivity in the brainstem of WT and MEV mice at postnatal days 4 (P4) and 14 (P14). Note that GFAP-IR is increased in MEV mice compared with the same brain regions of WT littermates. $B$, GFAP-IR in the brainstem of WT and MEV mice $3 \mathrm{~d}$ after facial nerve transection. Note that GFAP-IR is increased on the control, unoperated side in $\mathrm{MEV}$ mice (Con-MEV) (as well as in the whole brain) compared with the same region of normal littermates $(C o n-W T)$. $C$, The morphology of microglia, detected by $\alpha_{\mathrm{M}} \beta_{2}$-integrin immunoreactivity 2 and $3 \mathrm{~d}$ after facial nerve axotomy. Note that after facial nerve axotomy, the microglial cells in MEV mice are characterized by rounded, ameboid morphology with delayed and decreased ramification. $D$, Combination of $\left[{ }^{3} \mathrm{H}\right]$-thymidine autoradiography (white points) with either GFAP-immunoreactivity (green) or $\alpha_{\mathrm{M}} \beta_{2}$ integrin-IR (red) $3 \mathrm{~d}$ after facial nerve axotomy. Note that the proliferating cells in MEV mice are exclusively $\alpha_{\mathrm{M}} \beta_{2}$-integrin-positive microglia. Scale bars, $100 \mu \mathrm{m}$.

Ox42-IR shown in green) as well as on GFAP-positive astrocytes (Fig. 4C, GFAP-IR shown in green). No change in SHP1-IR was observed for neurons. On the unoperated side, some GFAP- positive astrocytes showed colocalization with SHP1 immunoreactivity. In the facial nerve axotomy model, the microglial and astrocytic SHP1-IR reached maximum intensity within 3-14 d after operation. At later time points (up to $84 \mathrm{~d}$ ), a faint staining for SHP1-IR became restricted to astrocytes (data not shown). After a direct cortical lesion, SHP1-IR was not only present in microglia and astrocytes but also in invading macrophages and T-lymphocytes (Fig. 4D). Preincubation of primary antibody with SHP1 peptide completely abolished specific SHP1 labeling (data not shown).

The specificity of the applied SHP1 antibody was characterized using Western blot analysis of total protein performed from lysates of facial nuclei (Fig. 3C). Facial motor nuclei homogenates from different time points after axotomy revealed a major band at $68 \mathrm{kDa}$, which corresponds to the molecular weight of the SHP1 protein in Jurkat $\mathrm{T}$ cells. The band intensity was markedly higher 3-14 d after axotomy and decreased at the later time points $(150 \mathrm{~d})$ but stayed elevated in comparison to the nonoperated controls. This was consistent with the time course of SHP1 immunohistochemistry.

\section{Cellular reactions in SHP1 mutant mice (me $/ \mathrm{mev}^{\mathrm{v}}$ ) in the intact brain and after peripheral or central lesion}

To elucidate functional aspects of SHP1 in the nervous system, we analyzed $\mathrm{me}^{\mathrm{v}} / \mathrm{me}^{\mathrm{v}}$ mice, which carry a defect in the phosphatase domain of SHP1 resulting in reduction of SHP1 activity. Immunostaining with anti-GFAP antibody, as a marker of early astrocytic activation, revealed a statistically significant increase in GFAP immunoreactivity $(p<0.05$ nonaxotomized facial nucleus; $p<0.001$ random brainstem area) throughout the whole intact brain in adult $\mathrm{me}^{\mathrm{v}} / \mathrm{me}^{\mathrm{v}}$ mice when compared with wildtype littermates (Figs. 5B, 6A). No incorporation of $\left[{ }^{3} \mathrm{H}\right]$ thymidine was found, indicating that in the normal adult brain GFAP-positive astrocytes do not proliferate in $\mathrm{me}^{\mathrm{v}} / \mathrm{me}^{\mathrm{v}}$ mice (data not shown). In addition, increased GFAP imunoreactivity through different intact brain regions was found in $\mathrm{me}^{\mathrm{v}} / \mathrm{me}^{\mathrm{v}}$ mice at postnatal days 4 and 14 compared with wild-type littermates (Fig. $5 A$ ). In contrast to the prominent increase in GFAP immunoreactivity in astrocytes, immunostaining with anti- $\alpha_{\mathrm{M}} \beta_{2}$ integrin antibody revealed that in intact brain regions of adult $\mathrm{me}^{\mathrm{v}} / \mathrm{me}^{\mathrm{v}}$ mice, the morphology (Fig. 5C) and number (Fig. 6B1) of labeled microglia were not conspicuously modified compared with wild-type littermates.

In response to peripheral nerve injury, posttraumatic increase of GFAP-IR in the axotomized facial nucleus was similar in $\mathrm{me}^{\mathrm{v}} / \mathrm{me}^{\mathrm{v}}$ mice and wild-type littermates (Fig. 6A). In contrast, the number of $\alpha_{\mathrm{M}} \beta_{2}$-positive microglia $(p<0.001)$ and the number of proliferating $\left[{ }^{3} \mathrm{H}\right]$-thymidine-labeled cells $(p<0.001)$ in $\mathrm{me}^{\mathrm{v}} / \mathrm{me}^{\mathrm{v}}$ mice were statistically significantly reduced by $40-$ $60 \%$ compared with wild-type littermates 2 and $3 \mathrm{~d}$ after facial nerve axotomy (Fig. 6B3). The combination of $\left[{ }^{3} \mathrm{H}\right]$-thymidine autoradiography and immunohistochemistry showed that the proliferating cells in $\mathrm{me}^{\mathrm{v}} / \mathrm{me}^{\mathrm{v}}$ mice were $\alpha_{\mathrm{M}} \beta_{2}$-integrin-positive microglia, whereas no GFAP-positive astrocytes were labeled (Fig. $5 D)$. After direct cortical lesion, the number of proliferating ([ $\left.{ }^{3} \mathrm{H}\right]$-thymidine-labeled) $\alpha_{\mathrm{M}} \beta_{2}$-positive microglia was also statistically significantly reduced in $\mathrm{me}^{\mathrm{v}} / \mathrm{me}^{\mathrm{v}}$ mice compared with wild-type littermates $(p<0.001)$ (Fig. 6B2). In the axotomized facial nucleus, only a small subset of $\alpha_{\mathrm{M}} \beta_{2}$-positive microglia achieved characteristic ramified morphology, as detected by light microscopy, whereas most activated microglia of mutant mice were rather rounded and ameboid (Fig. $5 C$ ). Hence, the ramification of microglia seemed to be delayed in $\mathrm{me}^{\mathrm{v}} / \mathrm{me}^{\mathrm{v}}$ mice at days 
A

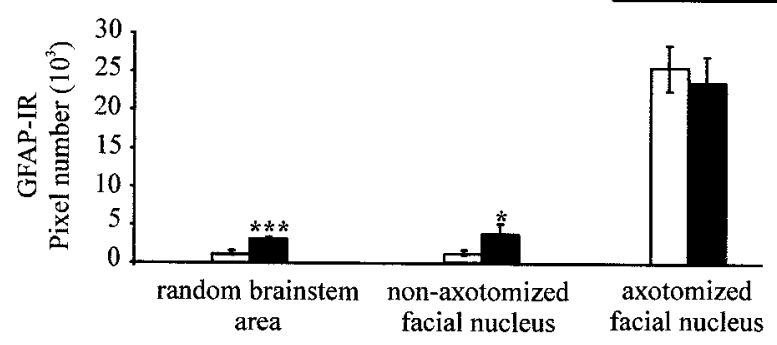

B1 UNINJURED BRAIN AREAS

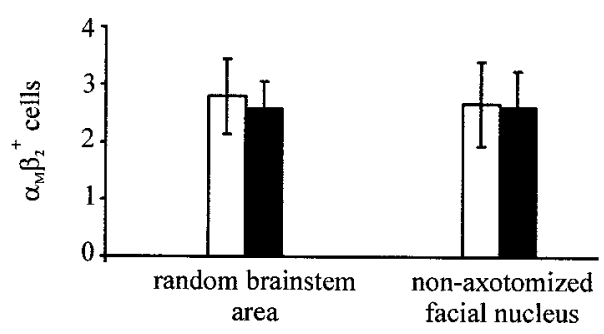

B2

AREA AFFECTED BY DIRECT CORTICAL LESION

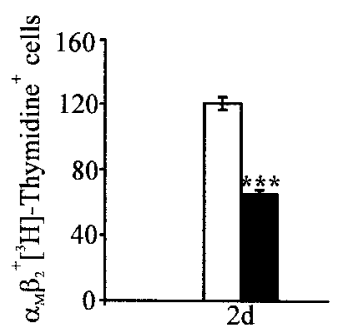

Days after direct cortical lesion

\section{B3}

\section{AXOTOMIZED FACIAL NUCLEI}

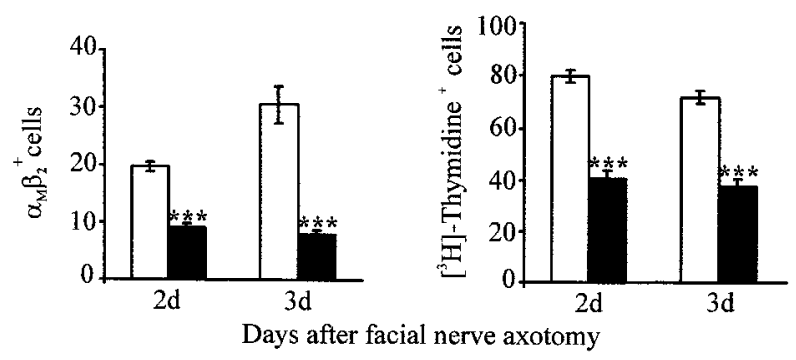

C

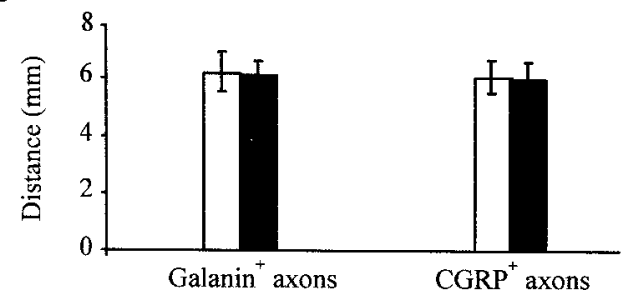

Figure 6. Quantitative effects of reduced SHP1 activity on astrocytic $(A)$ and microglial reaction $(B)$ in the intact and injured brain as well as on axonal outgrowth $(C) . A$, Quantification of GFAP-IR (pixel number) in the intact brain (random brainstem area, nonaxotomized facial nucleus)
3 (Fig. 5C) and 7 (data not shown) after facial nerve axotomy. At the ultrastructural level, the intracellular structures of neurons, microglia, or astrocytes did not show differences between $\mathrm{me}^{\mathrm{v}} /$ $\mathrm{me}^{\mathrm{v}}$ and wild-type mice (data not shown). When the neuronal responses in the axotomized facial nuclei between wild-type littermates and $\mathrm{me}^{\mathrm{v}} / \mathrm{me}^{\mathrm{v}}$ mice were compared, no difference could be detected for staining with an anti-galanin antibody (data not shown).

To examine the functional role of SHP1 during nerve regeneration, we compared the regeneration rate in $\mathrm{me}^{\mathrm{v}} / \mathrm{me}^{\mathrm{v}}$ mice and wild-type littermates using a facial nerve crush model. The facial nerve was crushed near the foramen stylomastoideum and allowed to regenerate for $4 \mathrm{~d}$. The longitudinal nerve sections were stained for neuropeptides galanin or CGRP (Fig. 6C), and the distance between the crush side and the most distal-labeled growth cone was measured using light microscopic grid scaling. At day 4, the regeneration distance for the wild-type littermates was $6.45 \pm 0.76 \mathrm{~mm}$ for galanin and $6.30 \pm 0.63 \mathrm{~mm}$ for CGRP immunoreactivity (Fig. 6C). A similar distance was also found for $\mathrm{me}^{\mathrm{v}} / \mathrm{me}^{\mathrm{v}}$ mice $(6.41 \pm 0.56 \mathrm{~mm}$ for galanin and $6.27 \pm 0.43 \mathrm{~mm}$ for CGRP-positive axons).

\section{In microglia and astrocytes, SHP1 is involved in different signaling transduction pathways}

After brain injury, growth factors such as CSF-1 and EGF as well as their receptors (CSF-1-R and EGF-R) are upregulated in microglial and astrocytic cells (for review, see Ferrer et al., 1996; Raivich et al., 1998). To determine whether SHP1 is involved in the signal transduction pathways of these receptor protein tyrosine kinases, we performed in vitro experiments. Microglial cells were stimulated with CSF-1 at different time intervals, and SHP1 was immunoprecipitated from nonstimulated and stimulated cells (Fig. 7A). Stimulation of microglial cells with CSF-1 induced increase in tyrosine phosphorylation of SHP1 and CSF$1-\mathrm{R}$, reaching a maximum after $30 \mathrm{~min}$, and declined after $60 \mathrm{~min}$. CSF-1 had no effects on the levels of SHP1 as shown in the blots probed with anti-SHP1 antibodies. To determine whether SHP1 might associate with CSF-1-R, blots of immunoprecipitates of SHP1 were probed with antisera against CSF-1-R. As illustrated in Figure $7 A$, an immunoreactive protein corresponding to CSF1-R was detected in SHP1 immunoprecipitates of both nonstimu-

$\leftarrow$

and $3 \mathrm{~d}$ after facial nerve axotomy in wild-type $(W T)$ littermates and MEV mice. Note that only in the uninjured brain regions there is a statistically significant increase for GFAP-IR in MEV mice compared with WT mice (6 sections per each animal; $n=4$ animals). B1, Quantification of $\alpha_{\mathrm{M}} \beta_{2}$-integrin-positive microglia in intact brain regions (random brainstem area and nonaxotomized facial nucleus). Note that the number of resting microglia is similar in WT and MEV mice. B2, Reduction in the number of proliferating $\left(\left[{ }^{3} \mathrm{H}\right]\right.$-thymidine-labeled) $\alpha_{\mathrm{M}} \beta_{2^{-}}$ positive microglia in MEV mice $2 \mathrm{~d}$ after direct cortical lesion. B3, Reduction in the number of $\alpha_{\mathrm{M}} \beta_{2}$-positive microglia and the proliferation rate $\left(\left[{ }^{3} \mathrm{H}\right]\right.$-thymidine-labeled cells) in MEV mice 2 and $3 \mathrm{~d}$ after facial nerve axotomy compared with wild-type littermates. The microglial reaction was always quantified in six sections per animal $(n=4)$. $C$, Four days after crush near the foramen stylomastoideum, the facial nerve was cut longitudinally and stained for galanin or CGRP, which accumulate in the terminals of the elongating neurites. The average distance between the most distal-labeled growth cone and the crush side was determined for each axonal marker in five tissue sections per animal $(n=6)$. Both the galanin- and CGRP-positive axonal populations show the same regeneration distance of $\sim 6 \mathrm{~mm}$ at day 4 in the WT littermates and MEV mice. All statistical analyses were performed using a paired, two-tailed Student's $t$ test. Statistically significant changes are indicated by asterisks $\left({ }^{*} p<0.05,{ }^{* * *} p<0.001\right)$. 
A

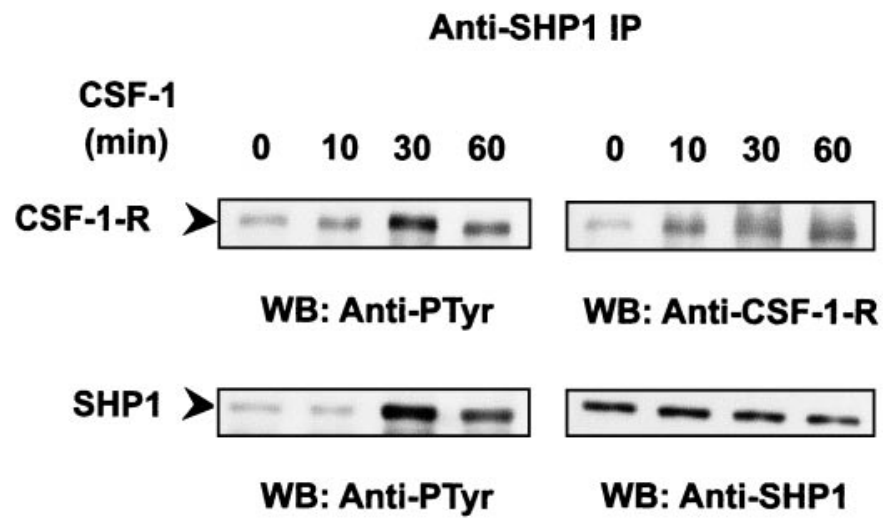

B

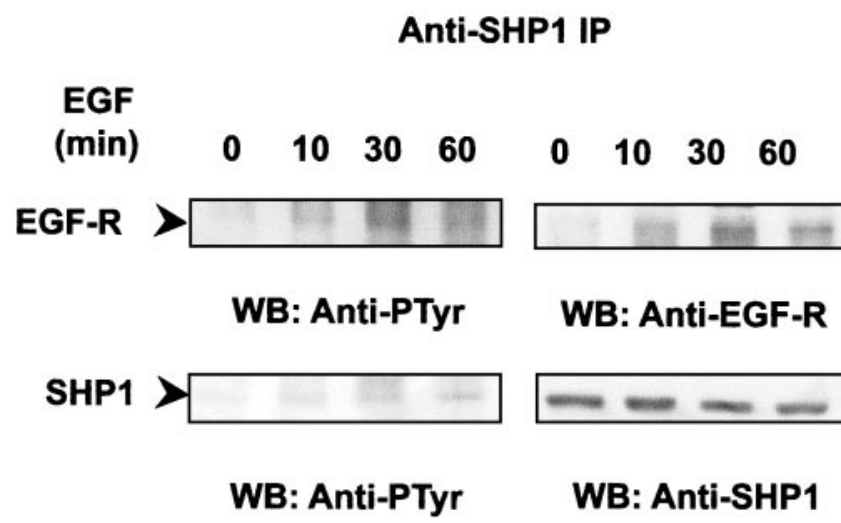

Figure 7. Association of SHP1 with CSF-1-receptor $(R)$ and EGFreceptor $(R)$. $A$, After $48 \mathrm{hr}$ starvation in serum-free medium, microglial cells were stimulated with CSF-1 $(200 \mathrm{ng} / \mathrm{ml})$ for $0,10,30$, and $60 \mathrm{~min}$ at $37^{\circ} \mathrm{C}$ and lysed in lysis buffer. Cell lysates were immunoprecipitated with an antiserum against SHP1. The proteins were resolved by SDS-PAGE, transferred to membrane, and probed with antibodies against phosphotyrosine (Anti-PTyr), CSF-1-R, or SHP1. The positions for the migration of CSF-1-R and SHP1 are indicated by arrows. Stimulation of microglial cells with CSF-1 induces increase in tyrosine phosphorylation of CSF$1-\mathrm{R}$ and SHP1. Tyrosine phosphorylation of both proteins reached a maximum after $30 \mathrm{~min}$ and declined after $60 \mathrm{~min}$. Note that CSF-1-R was detected in SHP1 immunoprecipitates of nonstimulated and CSF-1stimulated microglial cells. $B$, Cultured astrocytes were starved in serumfree medium for $48 \mathrm{hr}$, stimulated with EGF $(100 \mathrm{ng} / \mathrm{ml})$ for $0,10,30$, and $60 \mathrm{~min}$ at $37^{\circ} \mathrm{C}$, and lysed in lysis buffer. Cell lysates were immunoprecipitated with an antiserum against SHP1. After SDS-PAGE, proteins were transferred to membrane and probed with antibodies against phosphotyrosine (Anti-PTyr), EGF-R, or SHP1. The positions for the migration of EGF-R and SHP1 are indicated by arrows. EGF stimulation induces increases in tyrosine phosphorylation of EGF-R and SHP-1. Note that the amount of EGF-R detected in SHP1 immunoprecipitates was increased in stimulated cells and paralleled the level of EGF-R tyrosine phosphorylation.

lated and stimulated microglial cells. After CSF-1 stimulation, the amount of CSF-1-R coprecipitated with SHP1 was increased.

The potential association of SHP1 with EGF-R was examined in cultured astrocytes stimulated with EGF (Fig. 7B). SHP1 immunoprecipitates showed that EGF stimulation induced an increase in tyrosine phosphorylation of SHP1 and EGF-R. Tyrosine phosphorylation of both proteins reached maximum after
$30 \mathrm{~min}$ and declined after $60 \mathrm{~min}$. EGF did not have an effect on the level of SHP1, whereas the amount of EGF-R detected in SHP1 immunoprecipitates of stimulated astrocytes was increased and paralleled the level of EGF-R tyrosine phosphorylation.

\section{DISCUSSION \\ SHP1 expression and its possible role in the nervous system}

In hematopoietic cells, the role of protein tyrosine phosphatase SHP1 in signal transduction pathways of different cytokine receptors is well defined (Imboden and Koretsky, 1995). Although SHP1 has been detected by Northern blot analysis in the brain (Plutzky et al., 1992) and in cultured astrocytes (Massa and Wu, 1996), the expression and function of SHP1 in the normal and injured adult nervous system in vivo has not been investigated. In the present study we show that SHP1 is strongly expressed in astrocytes in ependymal and subependymal layers along the third and the fourth ventricles and the central canal of the spinal cord as well as in CA1, CA2, and CA3 regions of hippocampus and in dentate gyrus. A weak SHP1 expression is found in astrocytes dispersed in the gray matter of brain parenchyma, whereas Bergmann glia in cerebellum remain negative. In addition, SHP1 is also expressed in the pyramidal cells and their apical dendrites in the hippocampus and cortical layers II-IV.

In the adult SHP1 mutant $\mathrm{me}^{\mathrm{v}} / \mathrm{me}^{\mathrm{v}}$ mice, which are characterized by a reduction in SHP1 activity (for review, see Tsui and Tsui, 1994; Schultz et al., 1997), we found a strong increase in reactive astrocytes, evident by an increase in GFAPimmunoreactivity, throughout the whole intact brain. Neither the morphology nor the number of microglial cells appeared modified. Absence of ${ }^{3}[\mathrm{H}]$-thymidine-labeled nuclei indicated that the increase of GFAP-positive astrocytes did not result from astrocytic proliferation but rather from enhanced GFAP expression. In addition, the finding that GFAP immunoreactivity is increased through different intact brain regions in $\mathrm{me}^{\mathrm{v}} / \mathrm{me}^{\mathrm{v}}$ mice at postnatal days 4 and 14 suggests that this is rather an early event that develops during embryogenesis. Reactive astrocytes have also been noted in the transgenic mice overexpressing the IL-6 or CNTF cytokines, but in contrast to our results, an additional activation of resident microglial cells was observed (Chiang et al., 1994; Fattori et al., 1995; Winter et al., 1995). The lack of marked microglial activation in the intact CNS of $\mathrm{me}^{\mathrm{v}} / \mathrm{me}^{\mathrm{v}}$ mice indicates that the GFAP induction in $\mathrm{me}^{\mathrm{v}} / \mathrm{me}^{\mathrm{v}}$ mice is unlikely to be the result of elevated serum levels of cytokines such as IL-6, tumor necrosis factor, and IFN- $\gamma$ (Khaled et al., 1998), which affect both astroglial and microglial cell populations (for review, see Raivich et al., 1999). Thus, the astrocytic localization of SHP1 in the intact CNS in wild-type animals and the increase in GFAP immunoreactivity in postnatal and adult $\mathrm{me}^{\mathrm{v}} / \mathrm{me}^{\mathrm{v}}$ mice suggest that SHP1 is critical for the normal development of astrocytes as well as for initiation and maintenance of the reactive astrocytic phenotype.

Similar to the $\mathrm{me}^{\mathrm{v}} / \mathrm{me}^{\mathrm{v}}$ mice, reactive astrocytes without activation of microglia occur in the intact CNS of transgenic mice overexpressing TGF $\alpha$ (Rabchevsky et al., 1998), a growth factor that mediates its biological actions through EGF receptor (EGF-R) (for review, see Lee et al., 1995). Additionally, astrocytic localization of EGF-R in the same CNS regions as SHP1 (Nieto-Sampedro et al., 1988) as well as the appearance of EGF-R in reactive astrocytes (Ferrer et al., 1996) suggested that SHP1 might be involved in the EGF-R signaling cascade. This hypothesis was supported by our in vitro results, which demon- 
strated that in astrocytes after EGF stimulation, SHP1 was tyrosine-phosphorylated and associated with EGF-R. The interaction of SHP1 with the EGF-R transduction pathway has been already shown in human cervical carcinoma HeLa cells and embryonic kidney 293 cells (Su et al., 1996; You and Zhao, 1997). In astrocytes, the association with EGF-R occurred within the same period during which tyrosine phosphorylation of EGF-R was detected, indicating that SHP1 does not participate in dephosphorylation of EGF-R. This suggests that in astrocytes, SHP1 might act as a mediator to other intracellular signaling molecules in the EGF-R signaling cascade.

\section{A role for SHP1 in the glial cells after injury of the nervous system}

To investigate the expression and regulation of SHP1 after brain injury, we used two different models: transection of the peripheral nerves and direct cortical lesion. Both injury models have different functional outcomes in terms of restitution and neuronal survival. The peripheral motor nerve lesion causes a remote challenge to the motoneuron, which is accompanied by a controlled glial reaction. In contrast to most central neurons, motoneurons survive and regenerate their axons after peripheral nerve axotomy. The neural tissue remains intact, allowing the observation of the astrocytic reaction without scar formation (Streit et al., 1988). Furthermore, the blood-brain barrier is not disturbed, and therefore the microglial reaction can be studied in the complete absence of infiltrating hematogenous cells (for review, see Kreutzberg, 1996).

In both lesion models in wild-type animals, we found strong upregulation of SHP1 in microglia and moderate SHP1 upregulation in astrocytes on the injured side during the first week after injury. This time period coincides with the microglial proliferation, characterized by a four- to sixfold increase in microglial cell number (Graeber et al., 1988). In addition, in SHP1 mutant $\mathrm{me}^{\mathrm{v}} / \mathrm{me}^{\mathrm{v}}$ mice, a strong and selective inhibition of microglial proliferation after injury was observed, whereas the posttraumatic astrocytic reaction was similar to the wild-type littermates. This points to the question of whether SHP1 might be necessary for a stimulatory effect on microglial proliferation after brain injury. Similar to our data in the $\mathrm{me}^{\mathrm{v}} / \mathrm{me}^{\mathrm{v}}$ mice, an inhibition of microglial proliferation after facial nerve axotomy was observed in mice with a genetic deficiency in microglial mitogen CSF-1 (Raivich et al., 1994). These results, together with the previous data demonstrating that CSF-1-R is upregulated on microglia after brain injury (Raivich et al., 1998), suggested that in microglia SHP1 might be a part of the CSF-1-R signaling pathways. In our in vitro experiments we showed that SHP1 was constitutively tyrosinephosphorylated and associated with CSF-1-R in microglia. After CSF-1 stimulation there was an increase in tyrosine phosphorylation of SHP1 and an increase in the amount of coprecipitated CSF-1-R. Tyrosine phosphorylation CSF-1-R was increased during the whole period of stimulation, suggesting that SHP1 does not participate in the dephosphorylation of CSF-1-R. Thus, our in vitro results suggest that in microglia SHP1 might have a role as an adaptor molecule in CSF-1-R signaling cascades.

On the other hand, the reduction of microglial proliferation after brain injury in $\mathrm{me}^{\mathrm{v}} / \mathrm{me}^{\mathrm{v}}$ mice contradicts the observations that the cells of monocyte/macrophage lineage hyperproliferate in these mutant mice (Imboden and Koretsky, 1995). Although microglia and monocyte/macrophages show the antigenic and morphological similarities and are assumed to be of the same origin (for review, see Kreutzberg, 1996), our observation sug- gests that SHP1 might play a stimulatory role in microglial proliferation in response to injury. Such a stimulatory role for SHP1 in the mitogenic responses has already been shown for EGFactivated human embryonic kidney cells (Su et al., 1996). Furthermore, reduced proliferation of embryonic carcinoma cells after treatment with retinoic acid correlates with a reduction of SHP1 expression (Mizuno et al., 1997).

The reduced microglial response after injury in $\mathrm{me}^{\mathrm{v}} / \mathrm{me}^{\mathrm{v}}$ mice could also be indirectly influenced by changes in the reactive astrocytes, which have been shown to produce several microglial mitogens such as CSF-1, CSF-2, or IL-3 (Frei et al., 1985; Malipiero et al., 1990). These results, together with our observation that SHP1 was upregulated in activated astrocytes in the wild-type animals after injury, suggest that SHP1 might be involved in the synthesis of microglial mitogens. Thus, if the SHP1 activity is reduced, as in $\mathrm{me}^{\mathrm{v}} / \mathrm{me}^{\mathrm{v}}$ mice, the synthesis and release of microglial mitogens from astrocytes might be disturbed, resulting in an aberrant microglial reaction to brain injury.

In contrast to glial cells, the reduction of SHP1 activity in $\mathrm{me}^{\mathrm{v}} / \mathrm{me}^{\mathrm{v}}$ mice did not appear to affect a process of facial nerve regeneration. Although it has been thought that glial activation supports nerve regeneration (Streit, 1993), recent studies showed that cytostatic ablation of proliferating microglia with cytosinearabinoside does not affect the speed of axonal regeneration in the hypoglossal nerve (Svensson and Aldskogius, 1993). A similar absence of effect on the regenerating facial nerve is observed in mice with a genetic deficiency in CSF-1 (G. Raivich, personal communication). These results together with our data support the hypothesis that glial activation after nerve injury does not have a major influence on the neuronal regeneration program. On the other hand, it has been suggested that glial response has a rather anti-infectious role protecting the damaged neurons from possible infection (Raivich et al., 1999).

In summary, the present results emphasize that the intracellular signaling molecule SHP1 is an important mediator of different signaling pathways in astrocytes and microglia. In astrocytes, SHP1 might be involved in the regulation and maintenance of astrocytic activation in the intact brain. After injury, SHP1 seems to be involved in a complex of different glial activation processes in addition to its role in the immune reaction at the nerve lesion. The lack of SHP1 suppresses microglial proliferation similar to what can be found in CSF-1 knock-outs. This stresses the idea that SHP1 has a different function in signal transduction depending on the cell type and tissue environment.

\section{REFERENCES}

Chen HE, Chang S, Trub T, Neel BG (1996) Regulation of colonystimulating factor 1 receptor signaling by the $\mathrm{SH} 2$ domain-containing tyrosine phosphatase SHPTP1. Mol Cell Biol 16:3685-3697.

Chiang CS, Stalder A, Samimi A, Campbell IL (1994) Reactive gliosis as a consequence of interleukin-6 expression in the brain: studies in transgenic mice. Dev Neurosci 16:212-221.

Ebadi M, Bashir RM, Heidrick ML, Hamada FM, Refaey HE, Hamed A, Helal G, Baxi MD, Cerutis DR, Lassi NK (1997) Neurotrophins and their receptors in nerve injury and repair. Neurochem Int 30:347-374.

Eddelston M, Mucke L (1993) Molecular profile of reactive astrocytes. Neuroscience 54:15-36.

Fattori E, Lazzaro D, Musiani P, Modesti A, Alonzi T, Ciliberto G (1995) IL-6 expression in neurons of transgenic mice causes reactive astrocytosis and increase in ramified microglial cells but no neuronal damage. Eur J Neurosci 7:2441-2449.

Ferrer I, Alcantar S, Ballabriga J, Olive M, Blanco R, Rivera R, Carmona M, Berruezo M, Pitarch S, Planas AM (1996) Transforming growth factor-alpha (TGF-alpha) and epidermal growth factor receptor (EGF-R) immunoreactivity in normal and pathologic brain. Prog Neurobiol 49:99-123.

Frei K, Bodmer S, Schwerdel C, Fontana A (1985) Astrocytes of the brain synthesize interleukin 3-like factors. J Immunol 135:4044-4047. 
Giulian D, Baker TJ (1986) Characterization of ameboid microglia isolated from developing mammalian brain. J Neurosci 6:2163-2178.

Graeber MB, Tetzlaff W, Streit WJ, Kreutzberg GW (1988) Microglial cells but not astrocytes undergo mitosis following rat facial nerve axotomy. Neurosci Lett 85:317-321.

Hager G, Eckert E, Schwaiger FW (1999) Semiquantitative analysis of low levels of mRNA expression from small amounts of brain tissue by nonradioactive reverse transcriptase-polymerase chain reaction. J Neurosci Methods 89:141-149.

Hol EM, Schwaiger FW, Werner A, Schmitt A, Raivich G, Kreutzberg GW (1999) Regulation of the LIM-type homeobox gene ISLET-1 during neuronal regeneration. Neuroscience 88:917-925.

Hunter T (1995) Protein kinases and phosphatases: the yin and yang of protein phosphorylation and signaling. Cell 80:225-236.

Imboden JB, Koretsky GA (1995) Intracellular signaling. Switching off signals. Curr Biol 5:727-729.

Janeczko K (1993) Co-expression of GFAP and vimentin in astrocytes proliferating in response to injury in the mouse cerebral hemisphere. A combined autoradiographic and double immunocytochemical study. Int J Dev Neurosci 11:139-147.

Karnitz LM, Abraham RT (1995) Cytokine receptor signaling mechanisms. Curr Opin Immunol 7:320-326.

Karp HL, Tillotson ML, Soria J, Reich C, Wood JG (1994) Microglial tyrosine phosphorylation systems in normal and degenerating brain. Glia 11:284-290.

Khaled AR, Butfiloski EJ, Sobel ES, Schiffenbauer J (1998) Functional consequences of the SHP-1 defect in moth-eaten viable mice: role of NF-kappa B. Cell Immunol 185:49-58.

Klingmuller U, Lorenz U, Cantley LC, Neel BG, Lodish HF (1995) Specific recruitment of SH-PTP1 to the erythropoietin receptor causes inactivation of JAK2 and termination of proliferative signals. Cell 80:729-738.

Kreutzberg GW (1996) Microglia: a sensor for pathological events in the CNS. Trends Neurosci 19:312-318.

Lee DC, Fenton SE, Berkowitz EA, Hissong MA (1995) Transforming growth factor alpha: expression, regulation, and biological activities. Pharmacol Rev 47:51-85.

Malipiero UV, Frei K, Fontana A (1990) Production of hemopoietic colony-stimulating factors by astrocytes. J Immunol 144:3816-3821.

Masliah E, Ge N, Mucke L (1996) Pathogenesis of HIV-1 associated neurodegeneration. Crit Rev Neurobiol 10:57-67.

Massa PT, Wu C (1996) The role of protein tyrosine phosphatase SHP-1 in the regulation of IFN-gamma signaling in neural cells. J Immunol 157:5139-5144.

Massa PT, Wu C (1998) Increased inducible activation of NF-kappaB and responsive genes in astrocytes deficient in the protein tyrosine phosphatase SHP-1. J Interferon Cytokine Res 18:499-507.

Mizuno K, Katagiri T, Maruyama E, Hasegawa K, Ogimoto M, Yakura H (1997) SHP-1 is involved in neuronal differentiation of P19 embryonic carcinoma cells. FEBS Lett 417:6-12.

Nieto-Sampedro M, Gomez-Pinilla F, Knauer DJ, Broderick JT (1988) Epidermal growth factor receptor immunoreactivity in rat brain astrocytes. Response to injury. Neurosci Lett 91:276-282.

Norenberg MD (1994) Astrocyte responses to CNS injury. J Neuropathol Exp Neurol 53:213-220.

Paulson RF, Vesely S, Siminovitch KA, Bernstein A (1996) Signaling by the $\mathrm{W} / \mathrm{K}$ it receptor tyrosine kinase is negatively regulated in vivo by the protein tyrosine phosphatase Shp1. Nat Genet 13:309-315.

Plutzky J, Neel BG, Rosenberg RD (1992) Isolation of a src homology 2-containing tyrosine phosphatase. Proc Natl Acad Sci USA 89:1123-1127.
Rabchevsky AG, Weinitz JM, Coulpier M, Fages C, Tinel M, Junier MP (1998) A role for transforming growth factor alpha as an inducer of astrogliosis. J Neurosci 18:10541-10552.

Raivich G, Moreno-Flores MT, Moller JC, Kreutzberg GW (1994) Inhibition of posttraumatic microglial proliferation in a genetic model of macrophage colony-stimulating factor deficiency in the mouse. Eur J Neurosci 6:1615-1618.

Raivich G, Bluethmann H, Kreutzberg GW (1996) Signaling molecules and neuroglial activation in the injured central nervous system. J Med 45:239-247.

Raivich G, Haas S, Werner A, Klein MA, Kloss Ch, Kreutzberg GW (1998) Regulation of MCSF receptors on microglia in the normal and injured mouse central nervous system: a quantitative immunofluorescence study using confocal laser microscopy. J Comp Neurol 395:342-358.

Raivich G, Bohatschek M, Kloss CU, Werner A, Jones LL, Kreutzberg GW (1999) Neuroglial activation repertoire in the injured brain: graded response, molecular mechanisms and cues to physiological function. Brain Res Brain Res Rev 30:77-105.

Rothwell NJ, Hopkins SJ (1995) Cytokines and the nervous system. II: Actions and mechanisms of action. Trends Neurosci 18:130-136.

Sanner CA, Murray M, Goldberger ME (1993) Removal of dorsal root afferents prevents retrograde death of axotomized Clarke's nucleus neurons in the cat. Exp Neurol 123:81-90.

Schultz LD, Rajan TV, Greiner DL (1997) Severe defects in immunity and hematopoiesis caused by SHP-1 protein-tyrosine-phosphatase deficiency. Trends Biotech 15:302-307.

Schwaiger FW, Hager G, Raivich G, Kreutzberg GW (1998) Cellular activation in neuroregeneration. Prog Brain Res 117:197-210.

Streit WJ (1993) Microglial-neuronal interactions. J Chem Neuroanat 6:261-266.

Streit WJ, Graeber MB, Kreutzberg GW (1988) Functional plasticity of microglia: a review. Glia 1:301-307.

Su L, Zhao Z, Bouchard P, Banville D, Fischer EH, Krebs EG, Shen SH (1996) Positive effect of overexpressed protein-tyrosine phosphatase PTP1C on mitogen-activated signaling in 293 cells. J Biol Chem 271:10385-10390.

Svensson M, Aldskogius H (1993) Regeneration of hypoglossal nerve axons following blockade of the axotomy-induced microglial cell reation in the rat. Eur $\mathrm{J}$ Neurosci 5:85-94.

Tacconi MT (1998) Neuronal death: is there a role for astrocytes? Neurochem Res 23:759-765.

Tsui FW, Tsui HW (1994) Molecular basis of the motheaten phenotype. Immunol Rev 138:185-206.

Werner A, Willem M, Jones LL, Kreutzberg GW, Mayer U, Raivich G (2000) Impaired axonal regeneration in $\alpha 7$ integrin-deficient mice. J Neurosci 20:1822-1830.

Winter CG, Saotome Y, Levison SW, Hirsh D (1995) A role for ciliary neurotrophic factor as an inducer of reactive gliosis, the glial response to central nervous system injury. Proc Natl Acad Sci USA 92:5865-5869.

Yi T, Ihle JN (1993) Association of hematopoietic cell phosphatase with c-Kit after stimulation with c-Kit ligand. Mol Cell Biol 13:3350-3358.

Yi T, Mui AL, Krystal G, Ihle JN (1993) Hematopoietic cell phosphatase associates with the interleukin-3 (IL-3) receptor beta chain and down-regulates IL-3-induced tyrosine phosphorylation and mitogenesis. Mol Cell Biol 13:7577-7586.

You M, Zhao Z (1997) Positive effects of SH2 domain-containing tyrosine phosphatase SHP-1 on epidermal growth factor- and interferongamma-stimulated activation of STAT transcription factors in HeLa cells. J Biol Chem 272:23376-23381. 